\title{
Improving Students Ability in Problem Solving and Creativity Through Project-Based Learning
}

\author{
Dadang Jaenudin*, Surti Kurniasih \\ Department of Science Education \\ Universitas Pakuan \\ Bogor, Indonesia \\ *djae_2575@yahoo.co.id
}

\author{
Galuh Rizky Amalia \\ SMA Yapida Gunung Putri Bogor \\ Bogor, Indonesia
}

\begin{abstract}
The aim of this research is to improve students' ability in problem solving and creativity through project-based learning (PBL) under biotechnology subject. This research is conducted in twelfth grade of SMA Yapida Gunung Putri Bogor. Quasi experiment with non-equivalent pretest-posttest control group design was used. Test instrument was used for measuring problem solving ability and creative thinking. The result shows that there is an improvement in problem solving and creative thinking ability in experimental class after applying projectbased learning. The score of $\mathbf{n}$-gain for problem solving ability in experimental group is 0.73 (high) and control group is 0.53 (medium). The n-gain score for creative thinking ability in experimental group is 0.73 (high) and in control group is 0.53 (medium). Hypothesis testing of n-gain score for problem solving and creative thinking skill is 0.001 (significant). Project based learning gives students learning experience which initiated with authentic and factual problem; therefore, it can help students in finding appropriate solution. In conclusion, project-based learning can be applied as alternative for improving students' ability in problem solving and creative thinking in high school students.
\end{abstract}

Keywords: project based learning, problem solving ability, creativity

\section{INTRODUCTION}

Biology is one of the lessons that can develop 21st century skill, which is students' life skill. Biology is a science that consists of content or material, method, product, attitude and technology. In order to the aim to be achieved, biology must be supported with appropriate learning activity provided by the teacher in accordance with 21 st century learning. According to Suprijono [1], lexically learning is a process, way, and act of learning one thing. Learning is a teachers' way in organizing environment where students is regarded as a subject and that learning is an interactive and constructive dialogue. In the $21 \mathrm{st}$ century, learning must enforce students' life skill and character building.

The 21st century skill demand students to have four skills all together, they are: critical thinking and problem solving, communication, collaboration and creativity. NEA (National Educational Association) [2] stated that if students are supposed to be successful in a competition within the global society, they must have skill in communication, being creative, critical thinking as well as being able to work with other people. Students' skill need to be developed by the teacher in order to establish qualified human resources that can face competition in any fields, especially science and technology.

In reality, the difficulty in applying teaching learning process to improve students' skill is still high. As an implication, many teachers choose to teach using conventional model or approach. Teachers are not yet capable in applying various constructivism's learning model. According to the result of TTCT (Torrance Test of Creative Thinking) there is a decline in creative thinking which initiated in kindergarten age up to adult [3]. It is assumed to be the result of teacher centered learning approach applies by many teachers, which does not give enough room for students to be active during teaching learning process. Based on that fact it can be said that teachers are in need to apply better model for teaching that can improve students' skill in problem solving and creative thinking.

One of the methods in teaching that can develop students' attitude and way of thinking is project-based learning, which is a student center approach and provide meaningful learning experience for students. PjBL (Project based Learning) enables students to learn actively and combine creative thinking, collaboration, and problem solving [4]. Arnim, et.al. [5] said that PBL focuses on the development of a specific case study to create several alternative solutions.

Problem solving skill is a way in trying to find out a solution from a certain problem and achieve the desired goal. A process of finding the solution from a problem is an important thing [6]. According to Greenstein [7], There are five stages of solving problem. They are, understanding the problem, expressing all of the possible solution, designing plan on how to solve problem, execute the plan and evaluate the result.

The ability to solve problem in biology need to be developed, and one of the teaching learning in biology that can develop the ability to solve problem is biotechnology. Teachers are supposed to express a case study in general in order to challenge students to give creative and innovative ideas to solve it. 
As well as solving problem, creativity is a skill that the students must have. Creativity is a way of solving problem using several alternatives. The most important aspect of creativity is the ability to adapt towards a change and capable on solving any problem arises along the way, flexibility towards a situation and can think of alternative solution to a problem [8]. This indication shows that creative students can adapt in any kind of situations and conditions that require them to always find a solution to a problem they face. It is that this kind of condition that teachers must develop from the students.

Based on the explanation above, the aim of this research is to improve students' skill of 21 st century on biotechnology material in twelfth grade of senior high school through projectbased learning that can improve students' skill in problem solving and build creativity.

\section{METHODS}

This research is conducted in SMA Yapida Gunung Putri Bogor on December 2018 until May 2019. Quasi experiment method and nonequivalent pretest-posttest control group design is used in this research. Population in this research are twelfth grade science students of SMA Yapida which currently studying biotechnology. Purposive sampling technique, a technique which occupied under certain consideration, is used [9]. A Number of 30 students were involved for each experimental and control group. The variable that is measured is students' skill in problem solving and creative thinking. There are two aspects in assessing creativity variable, they are cognitive and psychomotor aspect. Instruments used is a test of the ability to solve problem, assessment for creativity cognitive aspect, which is creative thinking skill test, assessment for psychomotor aspect is product assessment sheet. The data collected in this research is quantitative data based on the calculation of $n$-gain score and inferential statistic. Inferential statistic consists of normality test, homogeneity test and hypothesis test. Data analysis collected from pretest and posttest for problem solving and creative thinking will be used to find out the score for $n$-gain. The category of $n$-gain score is described as follow (table 1):

TABLE I. CATEGORY OF N-GAIN SCORE

\begin{tabular}{|l|l|}
\hline \multicolumn{1}{|c|}{ Range } & \multicolumn{1}{c|}{ Category } \\
\hline $0.70-1.00$ & High \\
\hline $0.31-0.69$ & Medium \\
\hline $0-0.30$ & Low \\
\hline
\end{tabular}

The next step is to test the normality using Kolmogorov smirnov test with the help of SPSS software version 25 for windows. The testing criteria is based on significance level of $5 \%$ (>0.05). Homogeneity test is done using homogeneity of varians (levene statistic) with the help of SPSS software version 25 for windows. The criteria for testing is based on significance level of $5 \%(>0.05)$. Hypothesis testing is done using $\mathrm{T}$ test (Independent sample test) with testing criteria based on significance level of $5 \%(<0.05)$.

\section{RESULTS AND DISCUSSION}

The research result covers from problem solving test, creative thinking skill test and questionnaire for students' response on teaching learning process are shown in Figure 1 and 2 .

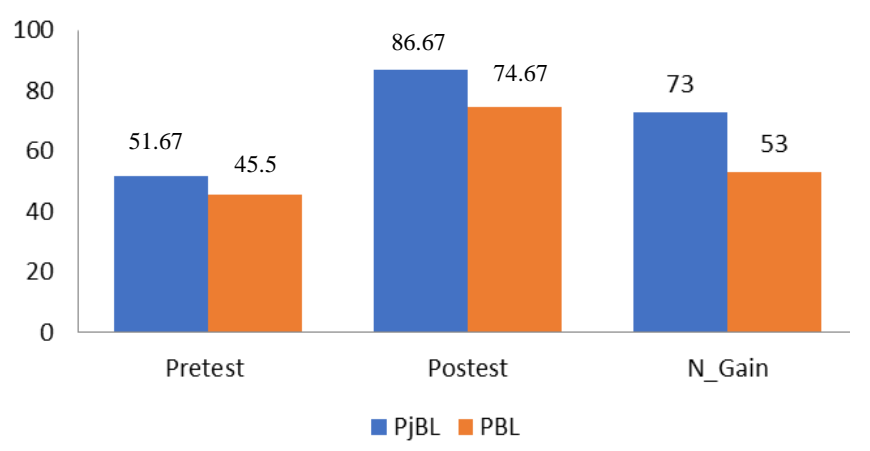

Fig. 1. The n-gain for problem solving skill.

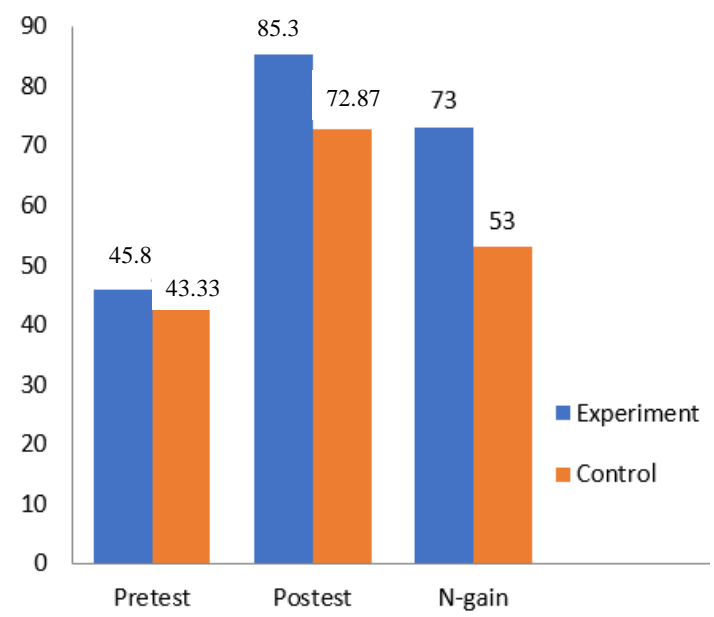

Fig. 2. Score of $n$-gain for creative thinking skill.

Figure 1 and 2 shows that there is an improvement both in control and experimental group. It is also point out that the improvement of students' problem solving and creative thinking skill score in experimental group is significantly higher compared to score in control group. Category of $n$-gain score for experimental group is high $(0.73)$ and as for control group is medium (0.53). Hypothesis testing for problem solving and creative thinking between control and experimental group is explained in figure 2 and 3.

TABLE II. Hypothesis TESTING SCORE OF N-GAIN FOR PROBLEM SOLVING SKILL

\begin{tabular}{|l|l|l|}
\hline \multicolumn{1}{|c|}{ Group } & \multicolumn{1}{|c|}{$\begin{array}{c}\text { Asymp. Sig. (2- } \\
\text { tailed) }\end{array}$} & \multicolumn{1}{c|}{ Verdict } \\
\cline { 1 - 1 } Control & \multirow{2}{*}{0.001} & Significance \\
\hline Experimental & \multicolumn{2}{|c|}{} \\
\hline
\end{tabular}


TABLE III. HyPOTHESIS TESTING SCORE OF N-GAIN FOR CREATIVE THINKING SKILL

\begin{tabular}{|l|l|l|}
\hline \multicolumn{1}{|c|}{ Group } & \multicolumn{1}{|c|}{$\begin{array}{c}\text { Asymp. Sig. (2- } \\
\text { tailed) }\end{array}$} & \multicolumn{1}{c|}{ Verdict } \\
\hline Experimental & 0.00 & Significance \\
\hline Control & 00 & \\
\hline
\end{tabular}

Table 2. shows that the result of t-test score of $n$-gain for problem solving skill in control group and experimental group with asymp Sig. 2-tailed level is $0.001<0.05$, therefore it can be concluded that $\mathrm{H}_{0}$ is rejected. It means that there is significance different on problem solving skill in n-gain score between experimental group and control group. Table 3. Shows that the result of $\mathrm{T}$ test score of $\mathrm{n}$-gain for creative thinking in control group and experimental group with asymp Sig. 2-tailed level is $0.00<0.05$, it can be said that $\mathrm{H}_{0}$ is rejected which means there is a significance different in creative thinking skill on n-gain score between experimental and control group.

Analysis data on each indicator for problem solving and creative thinking is shown in figure 3 and 4.

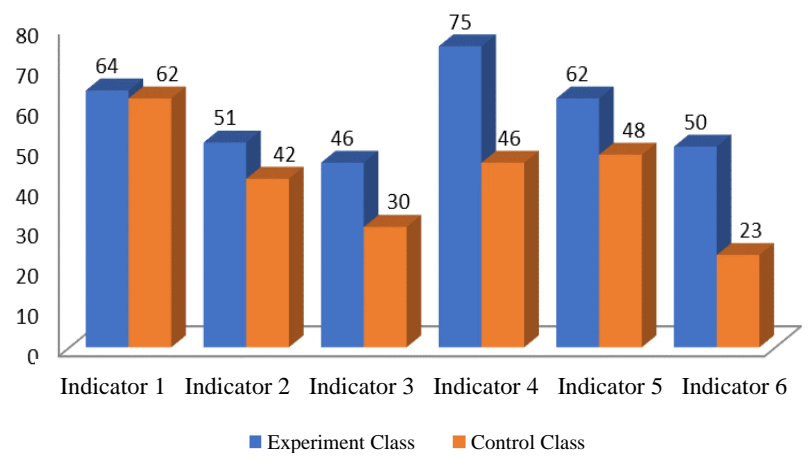

Fig. 3. The n-gain score for problem solving skill in each indicator.

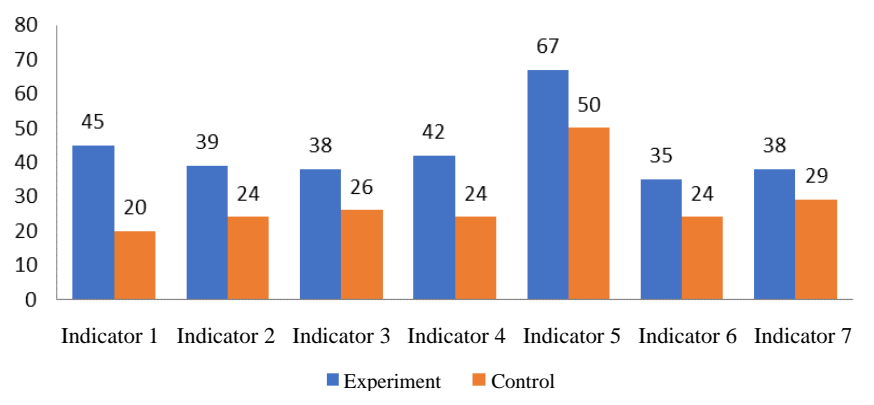

Fig. 4. The $n$-gain score for creative thinking skill in each indicator.

Figure 3. shows that $n$-gain score from each indicator of problem-solving skill in experimental group is higher than the control group. In the table it can be seen that the highest improvement happened during the stage of planning to solve problem, while the lowest improvement took place in the evaluation stage. The highest $n$-gain indicator in experimental group is planning for problem solving which is $(0.75)$ it can be considered as high while the lowest $n$-gain indicator is for expressing solution of a problem which around (0.46) it is considered as medium. The highest $\mathrm{n}$-gain indicator in control group is for understanding problem $(0.62)$ it is considered as medium while the lowest indicator is evaluation (0.23) it is considered as low category.

Figure 4. Shows that the highest score in experimental group can be found in the fifth indicator with average n-gain score 0.67 and the lowest score is in the sixth indicator with average $\mathrm{n}$-gain score 0.35 . On the other hands, the highest score in control group can be found in the fifth indicator 0.50 and the lowest score is the first indicator 0.20.

The ability to solve problem is one of the ability that senior high school students must have. Kubiatko and Vaculova [10] stated that the syntax of project based learning can improve skill in solving problem. The ability to solve problem is needed to help solve problem about the improvement of food quality that gives good nutrition for the body through biotechnology product. As it was stated by Harmer [11] that project-based learning improved frequency of problem-solving during teaching learning in classroom.

In the experimental group project-based learning is focused on how to come up with a product as a way of solving problem, in that way students will have an authentic learning experience compared to control group (PBL) which only focused on learning process [12].

Arnim, et.al. mentioned that project-based learning used in experimental group produce solutions to solve problem and focus on the development of product as a solution to a problem. In experimental class, teacher proposed a case study which will lead the students to apply their skill, finding information and being creative in order to solve the problem [13] The ability to solve problem can be developed throughout the whole stages of project-based learning.

Creative thinking skill is one of the skills that must be master by students, especially high school students in the coming $21^{\text {st }}$ century era. Creativity is an effort to realize renew ableness from a product [14] Students are set into factual and authentic learning condition during project-based learning. The learning process is started with students given orientation on the problem that needs to be solved. Students, then, give ideas and opinions. During project-based learning students are also encouraged to learn collaboratively, in order for active communication to take place among students which in turn will develop thinking process. Creativity is needed in designing an original and well accepted product. Creative thinking and problem-solving skill is needed in teaching learning process. Observation result validate that students' creativity develop more when students plan a design for a product to overcome problem. Product design can develop students' creative thinking through the creation of biotechnology product idea [15].

Statistics testing is also done for every indicators of creative thinking skill on instrument item tested to the students. The result shows that on every indicator creative thinking skill there is an improvement on posttest score compared to pretest. Project based learning can encourage students to learn pass the boundaries, so that they can maximize their thinking skill 
[4] F. Movahedzadeh, R. Patwell, and T. Gonzales, Project Based Learning to promote Effective learning in Biotechnology Course. Education Research International. 2012. 1-8. 2012.

interact freely and responsive learning environment will help students to improve learning process into more active and innovative $[11,14]$.

\section{CONCLUSIONS}

Project based learning model gives students a chance to develop their knowledge, to solve a problem and design a product. The use of project-based learning improves students' skill in solving problem and creative thinking compared to conventional method. The improvements on problem solving skill and creative thinking happen on each indicator for problem solving stage and creative thinking. Students give positive response upon the application of project-based learning. Teaching learning of biotechnology using projectbased learning is conducted as planned. All of the activities run perfectly well $(100 \%)$ with 6 learning steps which devided into 5 meetings.

\section{REFERENCES}

[1] H.K. Kim, The Creativity Crisis: The Decrease in Creative Thinking Scores on the Torrence Test of Creative Thinking. Creative Research Journal. 2(4). 285-295. 2011.

[2] A. Suprijono, Cooperative Learning (Teori \& Aplikasi PAIKEM). Yogyakarta: Pustaka Pelajar. 2013.

[3] National Education Association, Preparing 21st Century Student for a Global Society: An education Guide to the "Four cs". Alexandria, VA: Nasional Education Association. 2012.
[5] A. Wiek, A. Xiong, K. Brundiers, S. Van Der Leeuw, Integrating Problem and Project based Learning into Sustainability Programs. International Journal of Sustainability in Higher Education. 15(4). 431 449. 2014.

[6] C.L. Chiang and H. Lee, The Effect Of Project Based Learning On Learning Motivation and Problem Solving Ability of Vocational High School Student. International Journal of Information and Education Technology. 6(9), 709-712. 2016.

[7] L. Greenstein, Assessing 21st country kill: A Guide to Evaluating mastery and Authentic Learning. USA: Corwin A Sage Company. 2012.

[8] G. Krumm, V.A. Fillipppetti, V. Lemos, and J. Koval, Construct Validity and Factorial Invariance across sex of the Torrance Test of Creative Thinking- Figural Form A in Spanish- speaking children. Thinking Skill and Creativity. 22. 180-189. 2016.

[9] Sugiyono, Metode Penelitian Pendidikan (PendekatanKuantitatif, Kualitatif, dan R\&D). Bandung: Alfabeta. 2009.

[10] M. Kubiatko and I. Vaculova, Project Based Learning: Characteristic and The Experiences with Application in The Science Subjects. Energy Education Science and Technology. 3(1). 65-74. 2011.

[11] N. Harmer, Project Based Learning: Literature Review. School of Geography, Earth and Environmental Sciences: Plymouth University. 2014.

[12] D. Kokotsaki, V. Menzies, and A. Wiggins, Project Based Learning: A Review of the literature. Improving School. 1-11. 2016.

[13] R. Hanney and M.S. Baden, The Problem of Project: Understanding the Theoritical Underpinnings of Project-Led PBL. London Review of Education. 11(1). 7-19. 2013.

[14] Slameto, Belajar dan Faktor-faktor yang Mempengaruhinya (edisi revisi). Jakarta: Rineka Cipta. 2013.

[15] I.F. Natadiwidjaya, A. Rahmat, S. Redjeki, and S. Anggraeni, S. How to Practice Creative Thinking Skill through Scaffolding on Biotechnology content? Journal of Physics Conferenseries.1013. 2018. 